\title{
IN-SITU STABILIZATION OF CLAYS WITH LIME, DOLERITE AND QUARTZITE POWDERS
}

\author{
Syed Husnain Ali SHAH ${ }^{1)}$ *, Muhammad ARIF ${ }^{2,3)}$, \\ Mohammad Amjad SABIR ${ }^{1)}$ and Javed IQBAL ${ }^{4,5}$
}

\author{
1) Department of Earth Sciences, COMSATS University Islamabad, Abbottabad Campus, Pakistan \\ 2) Department of Geology, University of Peshawar, Peshawar, Pakistan \\ 3) Department of Earth Sciences, Abbottabad University of Science and Technology, Havelian (Abbottabad), Pakistan \\ 4) Institute of Mountain Hazards and Environment, Chinese Academy of Sciences, Chengdu 610041, PR China \\ ${ }^{5)}$ Department of Earth Sciences, The University of Haripur, Pakistan
}

*Corresponding author's e-mail: shas.husnain@gmail.com

\begin{tabular}{l}
\hline ARTICLE INFO \\
\hline Article history: \\
Received 24 April 2020 \\
Accepted 30 July 2020 \\
Available online 20 August 2020 \\
\hline
\end{tabular}

\section{Keywords:}

Penetration resistance

Bearing capacity

Expansive Clay

Settlement

Foundations

Plasticity Index

Cohesion

Angle of Internal friction

\begin{abstract}
This study presents the results of in-situ field stabilization of clay soil using lime, dolerite and quartzite powders. The rock samples were collected from Oghi village and Misri Banda village of Khyber Pakhtunkhwa Province, Pakistan. A $415 \mathrm{~m}^{2}$ site comprised of loose clay in Haripur district of Khyber Pakhtunkhwa was selected for field stabilization. In order to implement the experimental plan, eight test pits were dug and soil samples were collected from each pit to determine their major geotechnical properties. The raw soil contained kaolinite, illite and montmorillonite and hence characterized as $\mathrm{CH}$ type according to the Unified Classification System. The addition of $6 \%$ lime was found to produce the most positive impact on soil properties. Following a steady augment by $10 \%$, a maximum of $30 \%$ dolerite and quartzite powders were separately mixed with each of the $6 \%$ lime-added soil samples. The resulting mixed soils were placed back into their respective pits and compacted using compaction vibrator. Standard penetration, field density and plate load tests were performed on each test pit. Finally, soil samples were extracted from all the test pits and the values of their direct shear box and Atterberg limits were measured. The results demonstrate that the addition of dolerite and quartzite leads to a significant increase in the bearing capacity, dry density, penetration resistance and angle of internal friction and thus improves the performance of the formerly lime-stabilized soil by drastically decreasing its compressibility. The resulting improvement is mainly due to the denser and less hydrophilic character of the constituents of the added rock powders as compared with the lime and raw soil. It has also been found that the magnitude of impact on the soil properties by dolerite and quartzite is notably different owing to the difference in mineralogical composition and physical characteristics of individual minerals present in both rock types. This study would help construction engineers for better soil treatment.
\end{abstract}

\section{INTRODUCTION}

Clay soils generally exhibit stiff behavior under dry condition but become weak upon saturation with water. Such soils are characterized as soils having low strength and high settlements (Mohamed et al., 2009). Seasonal moisture changes promote heaving and shrinkage of expansive clay soils that causes fracturing and buckling of the structure built on these soils which results in huge economic losses every year (Jones and Holtz, 1973; Jones and Jones, 1987; Nelson and Miller, 1992; Ghobadi et al., 2013). Fortunately, a process commonly referred to as soil stabilization, can significantly improve the geotechnical properties of clay soils which involves the addition and mixing of other materials to such soils (Firoozi et al., 2017).

Stabilization by a well thought process and using the most appropriate additive may lead to enhanced strength, durable stiffness and diminution in plasticity and swelling as well as shrinkage potential of the resulting soil (Naeini et al., 2012; Prusinski and Bhattacharja, 1999; Sherwood, 1993). Several additives (e.g., lime, cement, gypsum and fly ash) have been conventionally used for enhancing the mechanical properties of clay soils. Among these, the most used is lime. Lime stabilization technique has been practiced over 5000 years. McDowell (1959) indicated that lime was used as a stabilizer by Greeks and Romans. Several studies are available where lime has been used for stabilizing weak soils. Croft (1967) proposed that addition of lime considerably reduces the swelling potential, liquid limit and maximum dry density of soils and elevates the optimum water content, shrinkage limit and strength. Similarly, Sabry (1977) found that treatment with lime leads to beneficial modification of 
Table 1 Modal mineralogical composition and physical properties of rocks, and soil, and chemical composition of Lime.

\begin{tabular}{|c|c|c|c|c|}
\hline Sample & Dolerite & Quartzite & Lime & Soil \\
\hline Quartz (\%) & ---- & $80-90$ & ---- & 45 \\
\hline Plagioclase (\%) & $47-49$ & $4-12$ & ---- & 8 \\
\hline Microcline (\%) & ---- & $2-4$ & ---- & ---- \\
\hline Mica $(\%)$ & ---- & $1-2$ & ---- & ---- \\
\hline Clino Pyroxene $(\%)$ & $50-52$ & ---- & ---- & ---- \\
\hline Opaque minerals $(\%)$ & $3-12$ & ---- & ---- & ---- \\
\hline Water Absorption (\%) & 0.72 & 0.51 & --- & ---- \\
\hline Specific Gravity & 3.10 & 2.85 & 2.25 & 2.48 \\
\hline $\mathrm{Fe}_{2} \mathrm{O}_{3}(\%)$ & ---- & ---- & 4.51 & ---- \\
\hline $\mathrm{CaO}(\%)$ & ---- & ---- & 81.5 & ---- \\
\hline $\mathrm{SO}_{3}(\%)$ & ---- & ---- & 11.9 & ---- \\
\hline $\operatorname{MgO}(\%)$ & ---- & ---- & 2 & ---- \\
\hline Kaolinite $(\%)$ & ---- & ---- & ---- & 23 \\
\hline Illite $(\%)$ & ---- & ---- & ---- & 11 \\
\hline Montmorillonite (\%) & --- & ---- & ---- & 9 \\
\hline Calcite $(\%)$ & ---- & ---- & ---- & 4 \\
\hline
\end{tabular}

most of the significant engineering properties of soft soils, e.g. plasticity index, shrinkage, cracking and the California Bearing Ratio (CBR), strength, workability and permeability and eliminates almost all swelling problems. Research carried out by Mohamed et al. (2009) and Sherwood (1993) also shows improvement in the engineering properties of clay soils with the addition of lime. According to Bell (1996), lime can modify the properties of soil to some extent only. His study indicates that the optimum addition of lime for achieving maximum modification of soil is normally between 1-3 \% by weight. On the other hand, Basma and Tuncer (1991) indicated that 2-8 \% lime can be used to modify a soil to maximum extent and that further lime addition does not cause any considerable change in Atterberg limits. Keeping in view the limitations of lime stabilization of soils, scientists have started looking for other additives that can further improve lime-stabilized soils. For example, Al Swaidiani et al. (2016) used natural Pozzalana to enhance the Geotechnical properties of lime-stabilized soils. In this study, we used powders from two different types of rocks, namely dolerite and quartzite to further augment the lime-stabilized clay. The novelty of the study is that it involves in-situ stabilization and applies testing in both the field and laboratory, whereas most of the previous studies on soil stabilization with lime and other admixtures are based exclusively on laboratory testing. In other words, studies regarding in-situ stabilization of soil and application of field testing for direct determinations of geotechnical properties, e.g. bearing capacity and settlement are rare.

The current study focuses on in-situ stabilization of soil by mixing it with different proportions of lime and powders from dolerite and quartzite rocks and subjecting the resulting mixtures to a variety of field and laboratory tests.

\section{MATERIALS USED}

\subsection{LIME}

Hydrated lime, which is generally used for stabilization of clay soils was utilized in the current study. The properties of the lime used are listed in Table 1. Its ICL (initial consumption of lime) was determined using the BS1924 (1990) test method. The ICL testing is used to find out the minimum quantity of lime required for brining significant improvement in soil properties so that the pozzolanic reactions could take place. The $\mathrm{pH}$ value of the lime-soil-water solutions is determined and with the value of 12.4 or slightly lower, it was assumed that lime is still available for pozzolanic reactions. The amount of lime that increases the $\mathrm{pH}$ value beyond 12.4 is used for soil stabilization. The results demonstrate that addition of $6 \%$ lime gives the maximum $\mathrm{pH}$ value of 12.69 and that further lime addition does not change the $\mathrm{pH}$ significantly (Fig. 1). That is why $6 \%$ lime was used for in-situ stabilization of soil in the current study.

\subsection{ROCK SAMPLES}

Undisturbed samples of dolerite and quartzite were collected from the Oghi village and Misri Banda village of Khyber Pakhtunkhwa province (Fig. 2). The collected dolerite is found as a dyke cutting across the general strike of the host rocks. It is fine grained jet black in color with small whitish spots. The quartzite is fine to medium grained, light grey to pinkish grey in color and displays primary sedimentary structures including ripple marks, graded bedding and cross bedding. Thin sections were prepared in the Department of Geology, University of Peshawar, Pakistan and then studied using polarizing microscope in the Department of Earth Sciences, COMSATS University Islamabad, Abbottabad campus for the purpose of determining modal mineralogical composition of both the dolerite and 


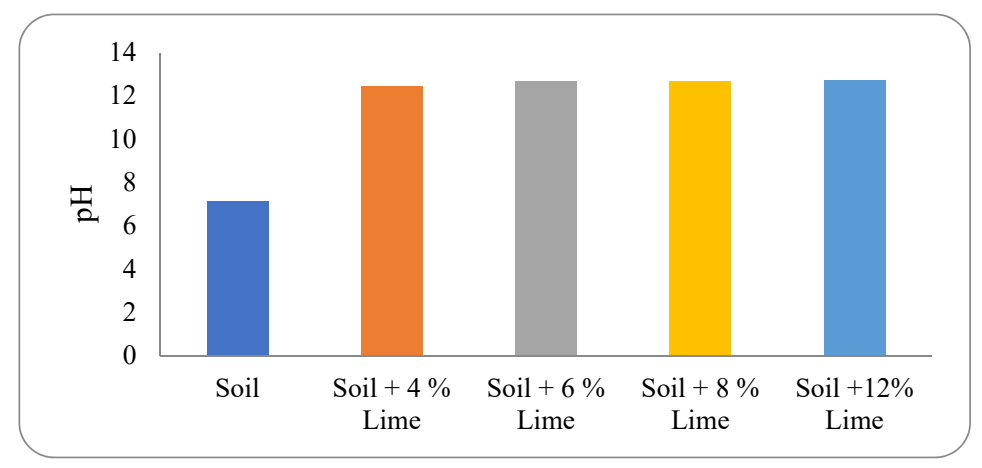

Fig. 1 Variation in $\mathrm{pH}$ of soil through Lime addition.

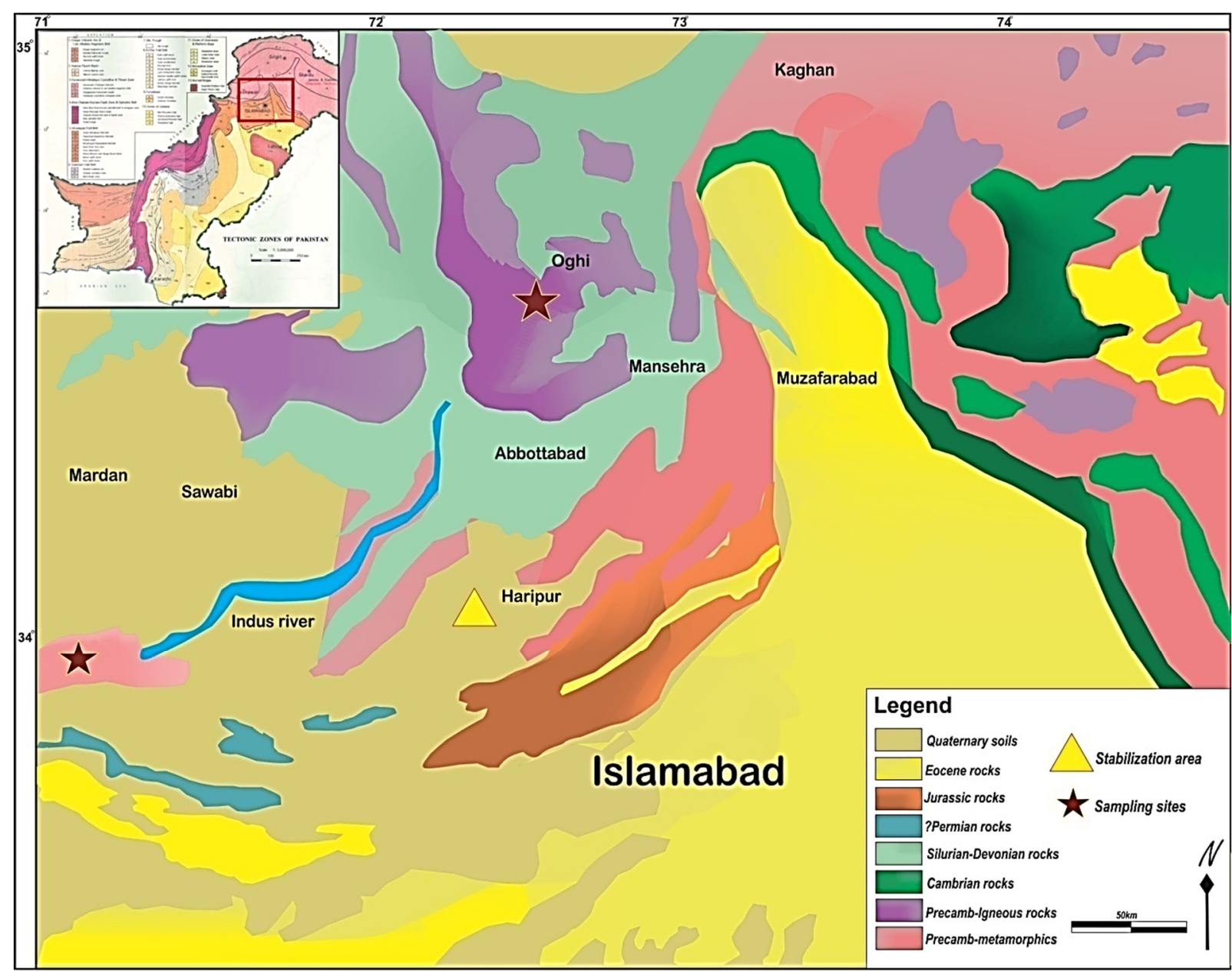

Fig. 2 Geological map showing location of the rock samples used and the site selected for stabilization (After Bakr, 1964).

quartzite samples. The dolerite sample is made up of Clinopyroxene, Plagioclase and opaque mineral(s) while the quartzite predominantly consists of quartz and minor amounts of plagioclase, microcline and mica (Figs. 3, 4 and Table 1). Water absorption capacity and specific gravity of both the rock samples were determined using the method given in ASTM D6473. Both the samples were then crushed, ground and the resulting powders were passed through different sieves to obtain their fine fractions (Fig. 5).

\section{METHODOLOGY}

A $415 \mathrm{~m}^{2}$ site consisting of weak and loose clayey soil with high moisture content was selected for field stabilization during the current investigation (Fig. 2). In order to implement the experimental plan, eight test pits, each having one-meter depth and 1.3- meter width were dug into the site. A small amount of soil was then collected from each pit for Xray diffraction (XRD) analysis and classification of the soil. Several tests, e.g. distribution of grain size, determination of Atterberg limits, specific gravity 


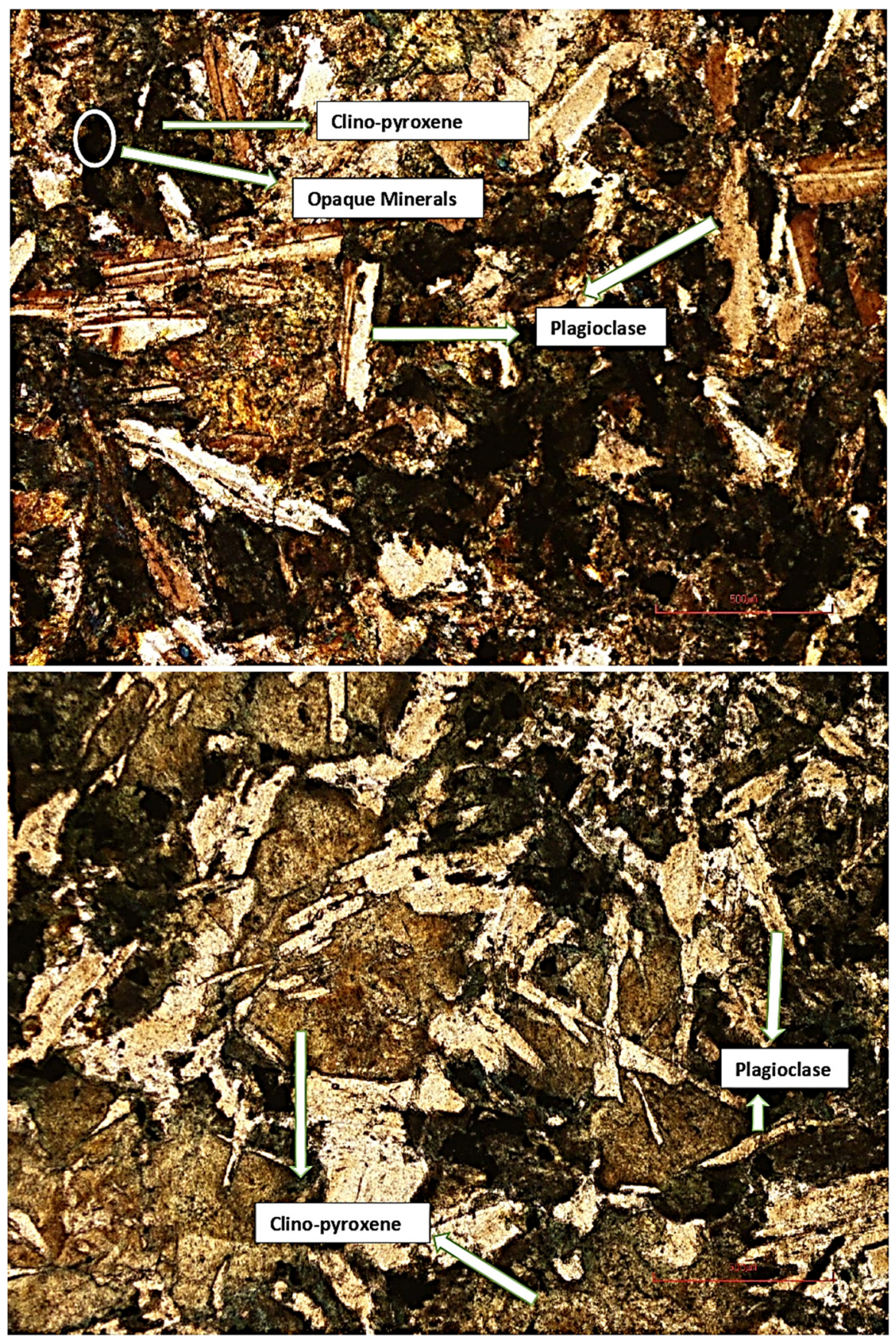

Fig. 3 Photomicrographs of the dolerite sample used for stabilization.

determination, and hydrometer analysis were performed on all the collected samples in accordance with the ASTM C136, ASTM D4318, ASTM D854 and ASTM D7928 respectively. The average results reveal that (i) $90 \%$ grains in soil from the study area are finer than 200 mesh size (Fig. 5), (ii) the finer than $200 \#$ mesh size material consists of $65 \%$ silt and $35 \%$ clay particles, and (iii) the soil belongs to $\mathrm{CH}$ type (fat clays) on the base of Atterberg limits and is composed of quartz, feldspar, kaolinite, illite and montmorillonites (Fig. 6; Tables 1 and 2).

The most influential lime percentage, i.e. $6 \%$ and different proportions of dolerite and quartzite powders were added and mixed with the soil excavated from each test pit (Table 3 ). These soils were allowed to dry in the natural heat and their optimum moisture contents were determined by using Proctor compaction test (ASTM D698). The resulting mixtures were then placed into the pits; optimum moisture contents were added and then compacted using Compaction Vibrator. Following compaction, different field tests were carried out in all the eight test pits. The tests conducted include Standard Penetration, Field Density determination using sand replacement method and Plate load test. The samples obtained from Standard Penetration and Field density tests were utilized for carrying out direct shear box test and measuring Atterberg limits. 

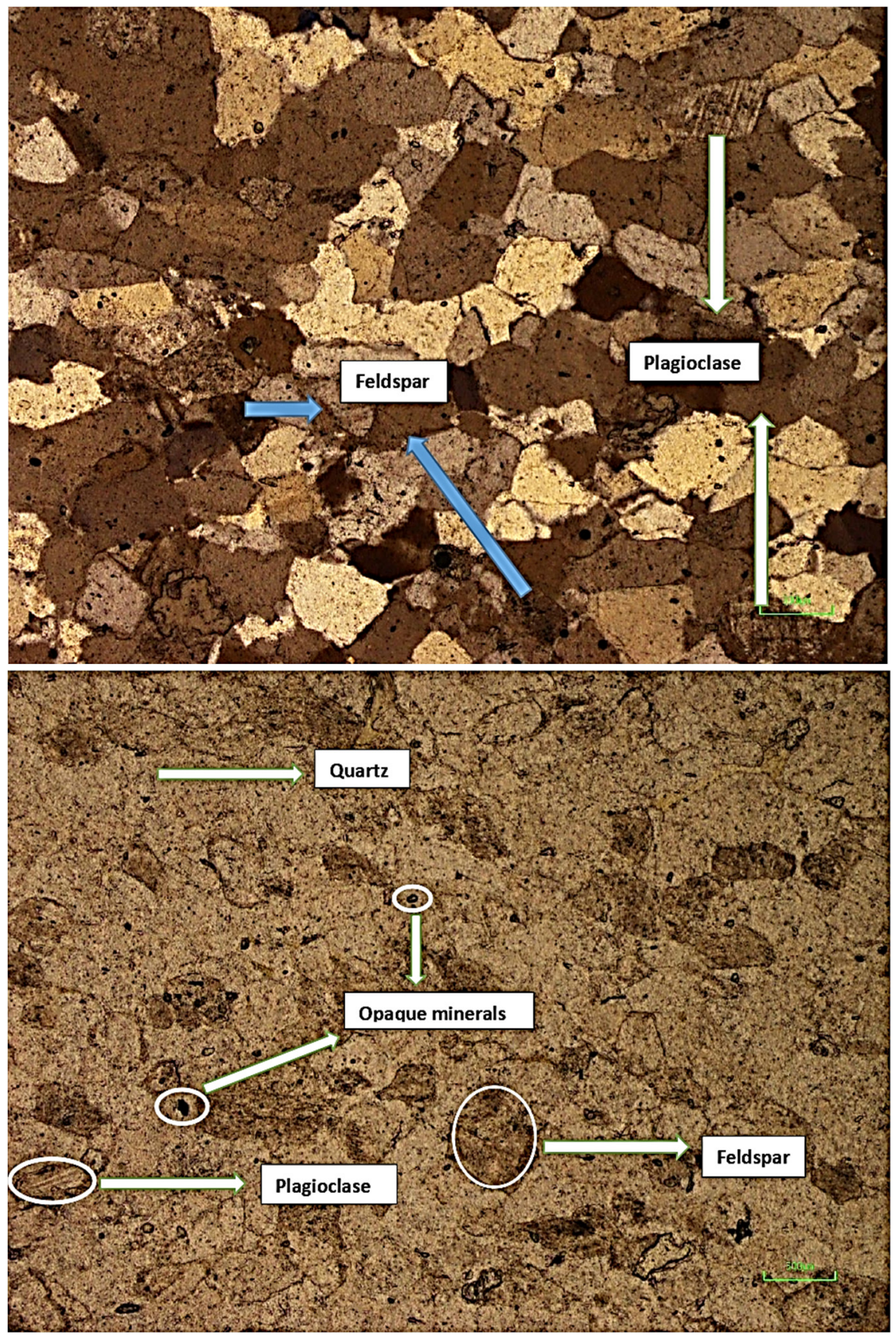

Fig. 4 Photomicrographs of the quartzite sample used for stabilization.

Table 2 Average values of Properties of Untreated Test pits soils for classification.

\begin{tabular}{lc}
\hline Specific Gravity & 2.48 \\
Liquid Limit (\%) & 53.9 \\
Plastic Limit (\%) & 23.7 \\
Plasticity Index (\%) & 30.2 \\
\hline
\end{tabular}

\subsection{STANDARD PENETRATION TEST}

The standard penetration test (SPT) was conducted following the procedure given in ASTM D1586. The SPT offers samples for laboratory testing and provide a measure of penetration resistance that can be used to determine bearing capacity of the soil. The penetration resistance is also referred to as $\mathrm{N}$ values. In the current study, the SPT-based $\mathrm{N}$ values were used to determine the allowable bearing capacity of ground using the Meryerhof's equation:

$\mathrm{Qa}=(\mathrm{N} / 6)[(\mathrm{B}+1) / \mathrm{B}]^{2} / \mathrm{K} \quad\left(\mathrm{kip} / \mathrm{ft}^{2}\right)$

Where,

$\mathrm{N}=$ Penetration resistance

$\mathrm{B}=$ Width of Footing (i.e. width of test pit in case of the current study)

$\mathrm{D}=$ Depth of Footing (i.e. depth of test pit in case of the current study)

$\mathrm{K}=1+0.33(\mathrm{D} / \mathrm{B}) \leq 1.33$

\subsection{PLATE LOAD TEST (PLT)}

Plate load test was performed in accordance with the ASTM D1195. This is the most important field test 
A

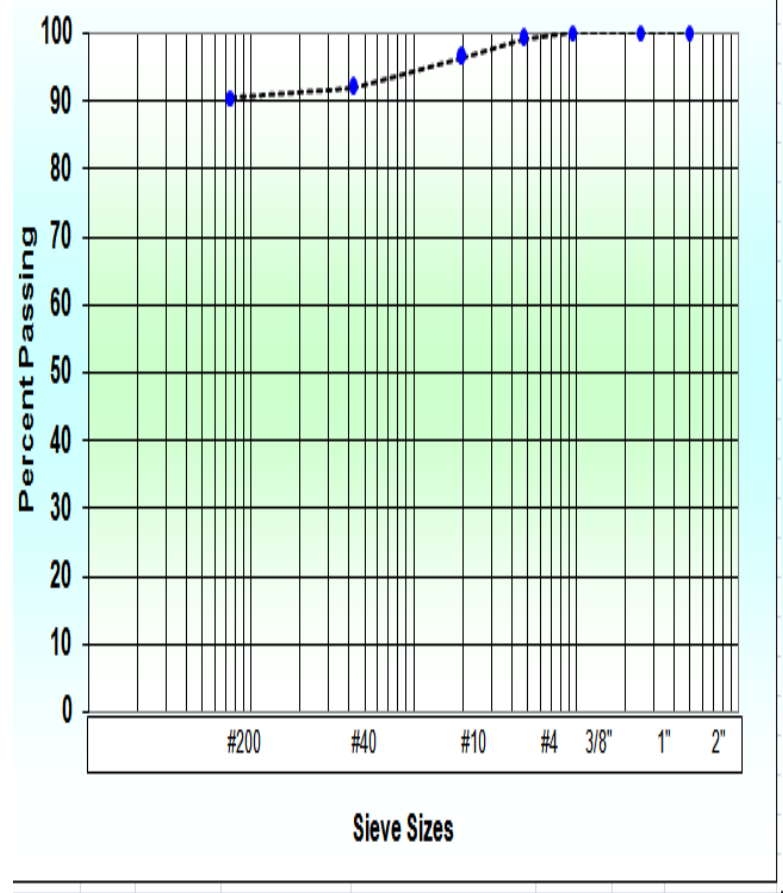

C

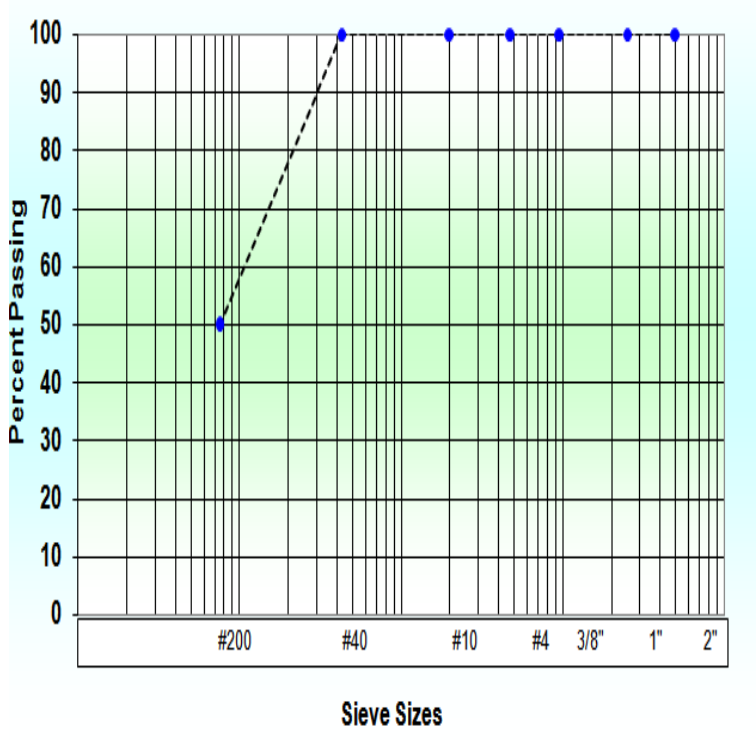

B

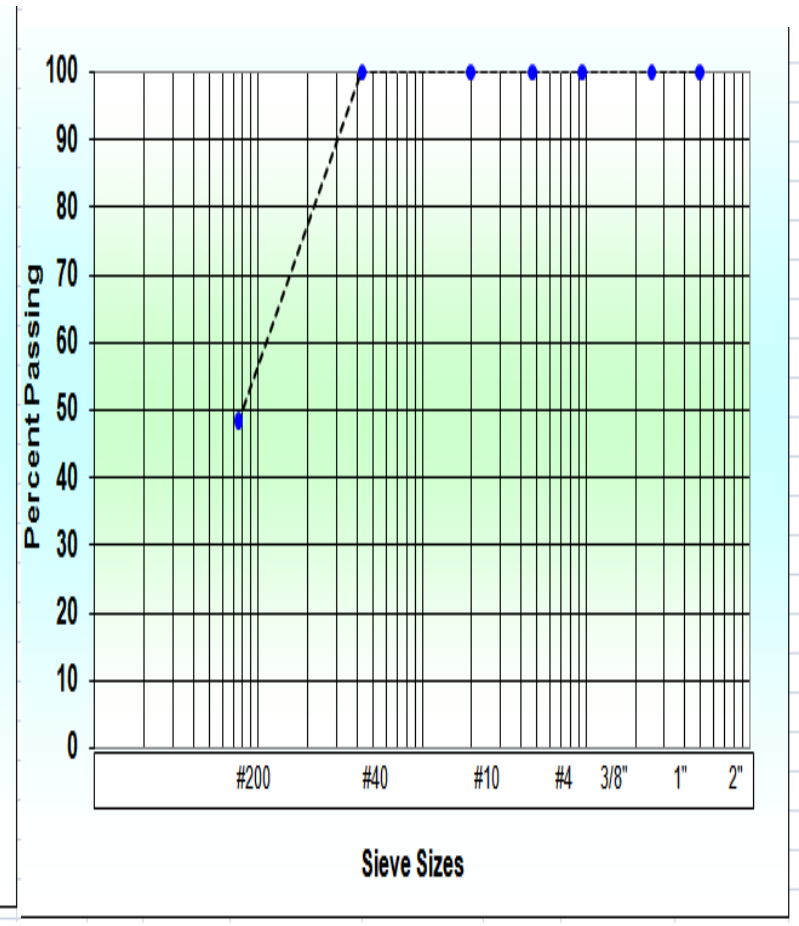

$\mathrm{D}$

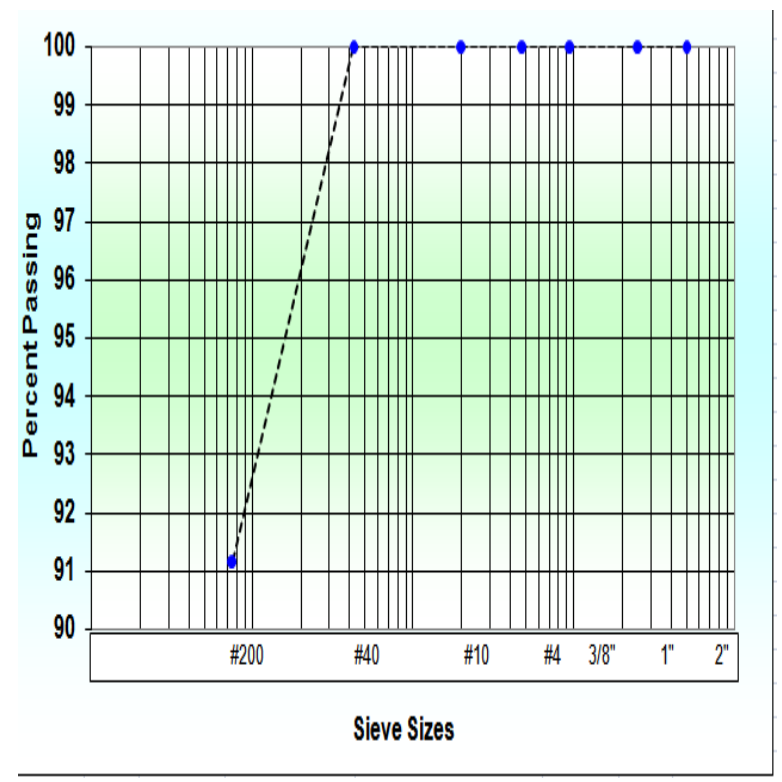

Fig. 5 Grain size distribution curves for soil samples collected from the stabilization site (A), dolerite (B), quartzite (C) and lime (D).

for designing shallow foundations and is conducted to evaluate the in-situ bearing capacity of soil and foundation settlement at the desired depth.

\subsection{FIELD DENSITY TEST (FDT)}

The ASTM D1556 method was used for performing the field density test to calculate the soil field density and moisture content. The resulting values were utilized for finding dry density of the soil.

\subsection{DIRECT SHEAR BOX TEST}

Using the ASTM D3080 method, the direct shear box test was performed for evaluating the soil's shear strength parameters, i.e. cohesion and angle of internal friction, that are used to determine the bearing capacities of shallow foundations.

\subsection{ATTERBERG LIMITS}

The Atterberg limits including liquid limit (LL), plastic limit (PL) and plasticity index (PI), were 


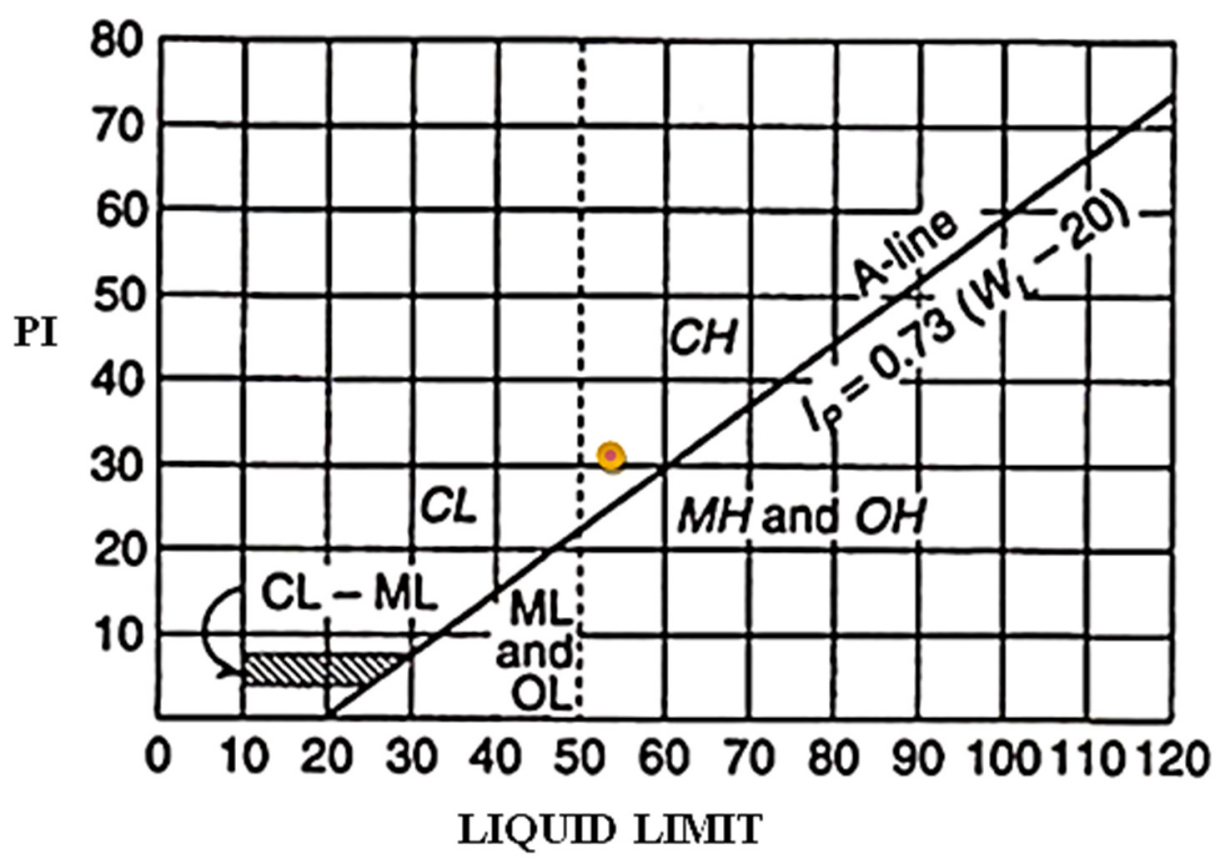

Fig. 6 Characterization of soil from the site selected for stabilization using the Unified scheme classification.

Table 3 Detail of the treatment process of soil with lime and rock powders and properties of the resulting samples $(\mathrm{St}=$ Settlement, $\mathrm{C}=$ Cohesion, $\mathrm{AIF}=$ Angle of internal friction, $\mathrm{PI}=$ Plasticity index $)$.

\begin{tabular}{clcccccc}
\hline $\begin{array}{c}\text { Test } \\
\text { Pits. }\end{array}$ & \multicolumn{1}{c}{ Description } & N values & $\begin{array}{c}\text { Dry Density } \\
\mathbf{k N / \mathbf { m } ^ { 3 }}\end{array}$ & $\begin{array}{c}\mathbf{S t} \\
\mathbf{m m}\end{array}$ & $\begin{array}{c}\mathbf{C} \\
\mathbf{k P a}\end{array}$ & $\begin{array}{c}\text { AIF } \\
\text { PI } \\
\mathbf{\%}\end{array}$ \\
\hline 1 & Pure soil & 5 & 16.58 & 46 & 12 & 9 & 30 \\
2 & Soil+6 \% lime & 6 & 15.3 & 41 & 13.1 & 11 & 18 \\
3 & Soil+6 \% lime+10 \% dolerite powder & 8 & 17.56 & 35 & 12.01 & 13 & 14 \\
4 & Soil+6 \% lime+20 \% dolerite powder & 10 & 18.83 & 29 & 11.1 & 15 & 11 \\
5 & Soil+6 \% lime+30 \% dolerite Powder & 13 & 19.9 & 22 & 9.3 & 18 & 7 \\
6 & Soil+6 \% lime+10 \% quartzite powder & 7 & 16.9 & 38 & 11.7 & 12 & 13 \\
7 & Soil+6 \% lime+20 \% quartzite powder & 9 & 17.7 & 33 & 09.99 & 14 & 9 \\
8 & Soil+6 \% lime+30 \% quartzite powder & 12 & 18.57 & 27 & 08.07 & 17 & 5 \\
\hline
\end{tabular}

determined using the ASTM D4318 method. Determination of the Atterberg limits is essential for characterizing soils on the basis of their plasticity. The LL and PL values were determined through digital apparatus, while the PI values were obtained by subtracting the values of PL from LL.

\subsection{FOUNDATION ANALYSIS}

A proper foundation analysis is required prior to commencing any constructional activity since foundation is the structure that transfers load of the superstructure to the ground. In case of the current study, the values of shear strength parameters and dry density were used for determining the bearing capacities using the Terzaghi bearing capacity equations:

For Strip footings:

$\mathrm{Qu}=\mathrm{c} \mathrm{Nc}+\gamma \mathrm{D} \mathrm{Nq}+0.5 \gamma \mathrm{B} \mathrm{N} \gamma$
For Square footings:

$\mathrm{Qu}=1.3 \mathrm{c} \mathrm{Nc}+\gamma \mathrm{D} \mathrm{Nq}+0.4 \gamma \mathrm{B} \mathrm{N} \gamma$

For Circular footings:

$\mathrm{Qu}=1.3 \mathrm{c} \mathrm{Nc}+\gamma \mathrm{D} \mathrm{Nq}+0.3 \gamma \mathrm{B} \mathrm{N} \gamma$

Where:

$\mathrm{Qu}=$ Ultimate Bearing capacity

$\mathrm{C}=$ Cohesion

$\gamma=$ Dry density of soil

$\mathrm{D}=$ Depth of Footing (i.e. depth of test pit in case of the current study)

$\mathrm{B}=$ Width of Footing (i.e. width of test pit in case of the current study)

$\mathrm{Nc}, \mathrm{Nq}$ and $\mathrm{N} \gamma=$ Bearing capacity factors as determined by putting the values of angle of internal friction in the Terzaghi chart (Fig. 7).

For the determination of Allowable bearing capacity, the Ultimate bearing capacity is divided with Safety factor (FS). The FS used in this study is " 3 ". 


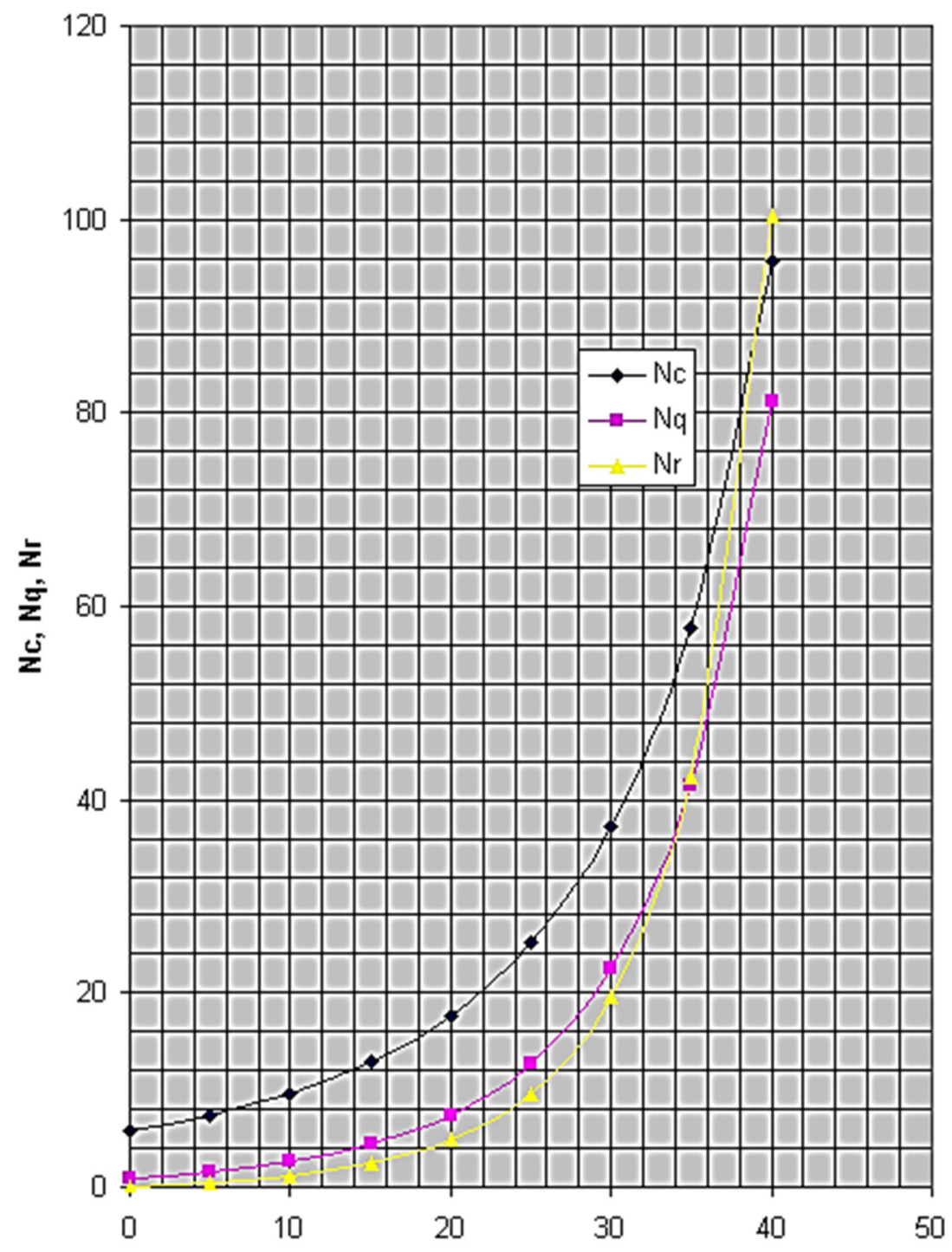

Fig. 7 Determination of bearing capacity factors using the Terzaghi chart.

\section{RESULTS AND DISCUSSION}

\subsection{FIELD TESTS}

Three types of in-situ (field) testing, namely Standard Penetration Test (SPT), Plate Load Test (PLT) and Field Density Test (FDT) were conducted during the current investigation. The values of penetration resistance and dry density were measured through SPT and FDT respectively, while the values of bearing capacity and settlement were calculated through PLT. The results indicate that the addition of $6 \%$ lime enhances the penetration resistance and bearing capacity and reduces the values of dry density and settlement (Tables 3, 4 and Figs. 8-10). For the purpose of greater accuracy and cross-checking, the bearing capacity was also determined from the values of penetration resistance and the results reveal that $6 \%$ lime addition has the potential to improve the ground's bearing capacity significantly (Table 4 ). This is due to the reason that addition of adequate amounts of lime and water facilitates decomposition of clay particles into silica and alumina, which react with calcium from the lime to form calcium-silicate-hydrates (CSH) and calcium-aluminate-hydrates $(\mathrm{CAH})$ respectively (Firoozi et al., 2017). Both the CSH and CAH are cementitious materials that constitute the matrix thus increasing the strength of the lime-stabilized clays by amplifying their penetration resistance and bearing capacity and reducing settlement. The observed decrease in dry density of the lime-stabilized soil can be attributed to the lower specific gravity of the added lime as compared to the untreated soil (Table 1). Besides, disturbance of soil grading due to aggregation of the soil particles consequent upon lime addition may also have accounted for the reduction of dry density (Ghobadi et al., 2013).

The gradual increasing addition of dolerite and quartzite powders to lime-stabilized soil samples leads to a regular increase in penetration resistance, dry 
Table 4 Detail of the general and shallow foundation bearing capacity values of soil stabilized with Lime and rock powders.

\begin{tabular}{ccccccc}
\hline $\begin{array}{c}\text { Test } \\
\text { Pit }\end{array}$ & \multicolumn{1}{c}{ Description } & $\begin{array}{c}\text { SPT } \\
(\mathbf{k P a})\end{array}$ & $\begin{array}{c}\text { Plate load } \\
\mathbf{( k P a )}\end{array}$ & $\begin{array}{c}\text { Strip } \\
\text { Footing } \\
(\mathbf{k P a})\end{array}$ & $\begin{array}{c}\text { Square } \\
\text { Footing } \\
(\mathbf{k P a})\end{array}$ & $\begin{array}{l}\text { Circular } \\
\text { Footing } \\
(\mathbf{k P a})\end{array}$ \\
\hline 1 & Pure soil & 48.2 & 49 & 51.4 & 62 & 61.7 \\
2 & Soil+6 \% lime & 57.8 & 59 & 61.8 & 74.7 & 74.2 \\
3 & Soil+6 \% lime+10 \% dolerite powder & 77.4 & 69 & 70.8 & 83.7 & 83.0 \\
4 & Soil+6 \% lime+20 \% dolerite powder & 97 & 80 & 81.7 & 94.7 & 93.5 \\
5 & Soil+6 \% lime+30 \% dolerite powder & 126 & 96 & 98.1 & 109.9 & 107.6 \\
6 & Soil+6 \% lime+10 \% quartzite powder & 67.8 & 62 & 63.6 & 75.5 & 74.9 \\
7 & Soil+6 \% lime+20 \% quartzite powder & 86.9 & 68 & 68.8 & 80 & 79 \\
8 & Soil+6 \% lime+30 \% quartzite powder & 116 & 83 & 81.7 & 91.8 & 90.0 \\
\hline
\end{tabular}

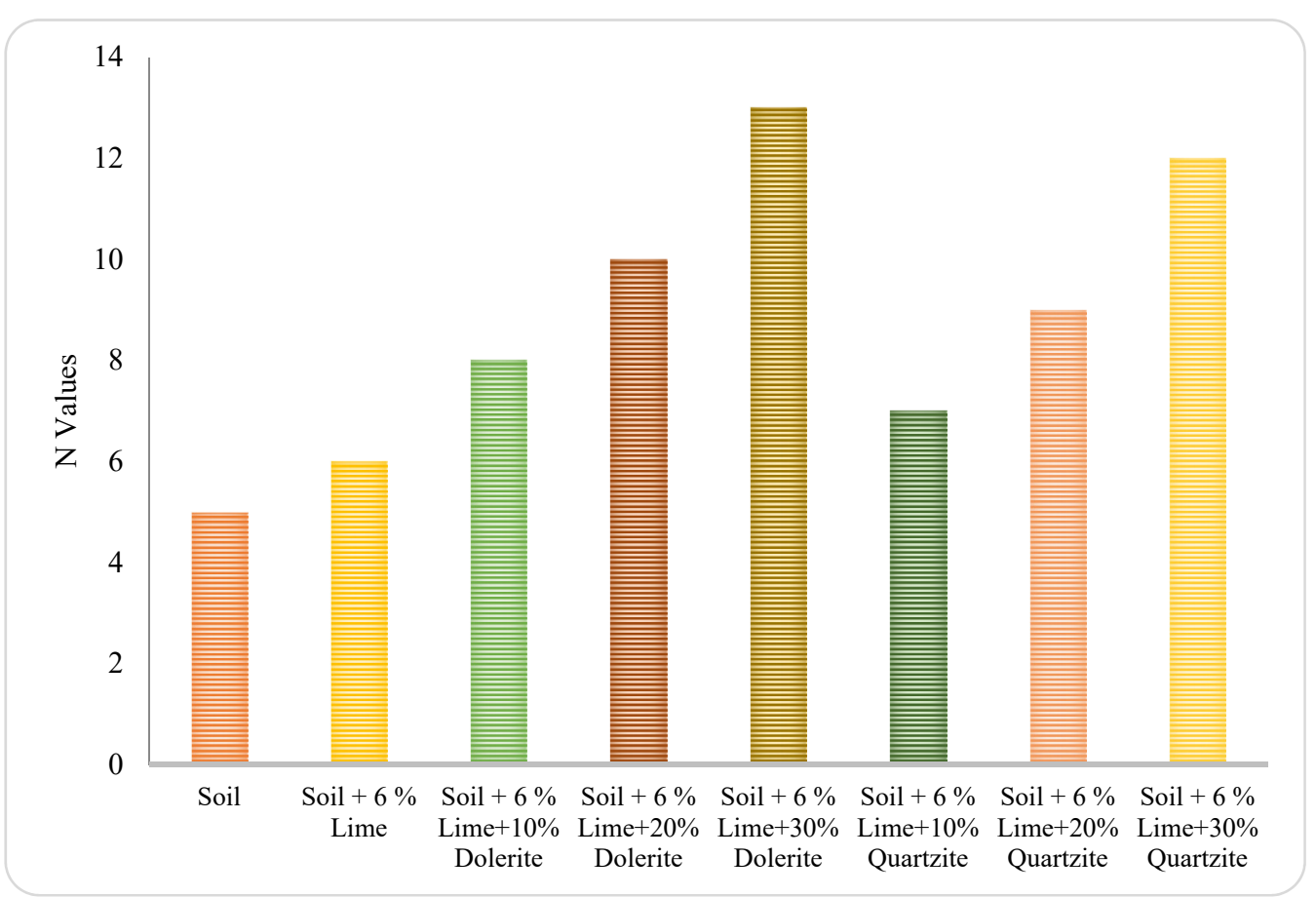

Fig. 8 Variation in $\mathrm{N}$ values of the original soil, soil stabilized with lime and lime-stabilized soil containing different proportions of dolerite and quartzite powders.

density as well as bearing capacity and reduction in settlement values to significant extents. The maximum improvement in the mentioned properties is achieved with the addition of $30 \%$ dolerite and quartzite powders. Results from PLT also demonstrate considerable boosting in the values of bearing capacity and lessening of the settlement values by adding $30 \%$ dolerite and quartzite powders (Tables 3, 4; Figs. 810). The observed improvement in penetration resistance, dry density, bearing capacity and settlement is most probably due to the higher specific gravity and larger grain size of the added rock powders as compared to both the lime and original soil. The higher specific gravity of dolerite and quartzite is attributed to their content of denser minerals including clinopyroxene, quartz and feldspars (Table 1). The dolerite and quartzite powders have less than $55 \%$ of their grains finer than 200\# mesh while $90 \%$ of the grains in both lime and soil are finer than 200\# mesh size (Fig. 5). This coarser grain size and high specific gravity of dolerite and quartzite enable the limestabilized soil to achieve higher density through compaction that in turn improves the values of bearing capacity, penetration resistance and settlement.

\subsection{PLASTICITY INDEX AND SHEAR STRENGTH PARAMETERS}

The original soil from the study area possesses high plasticity index (PI) and low specific gravity (Table 2). It contains Ca-montmorillonite and thus generally classifies as $\mathrm{CH}$ soil (Fig. 6). The montmorillonite can absorb and hold large amounts of water in its inter-ionic layers that enhances the soil's PI and makes it swell causing settlement (Javed et. al., 2018; Xu et. al., 2014). Results from the tests for determining the soil's PI and shear strength, performed on samples obtained through SPT and FDT, demonstrate that addition of $6 \%$ lime drastically 


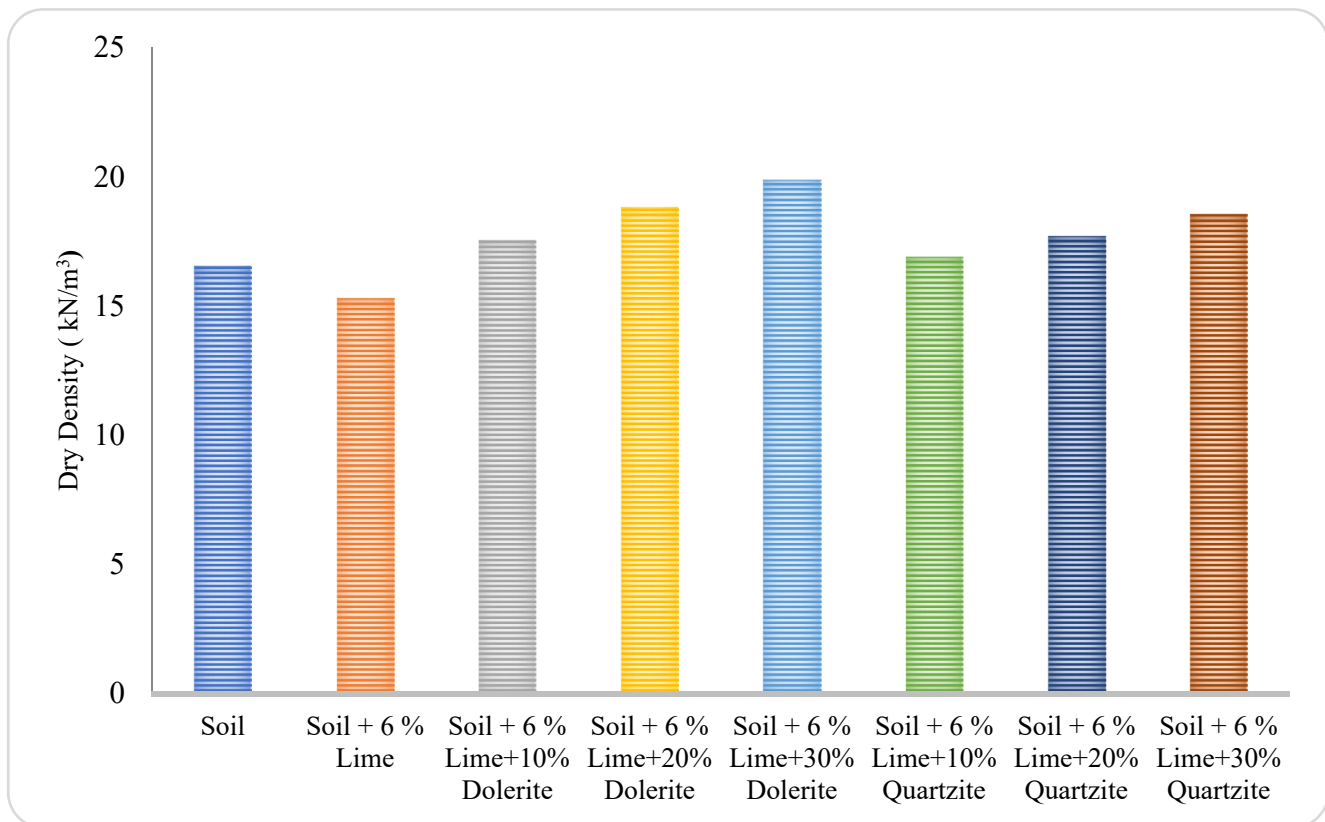

Fig. 9 Variation in dry densities of the original soil, soil stabilized with lime and lime-stabilized soil containing different proportions of dolerite and quartzite powders.

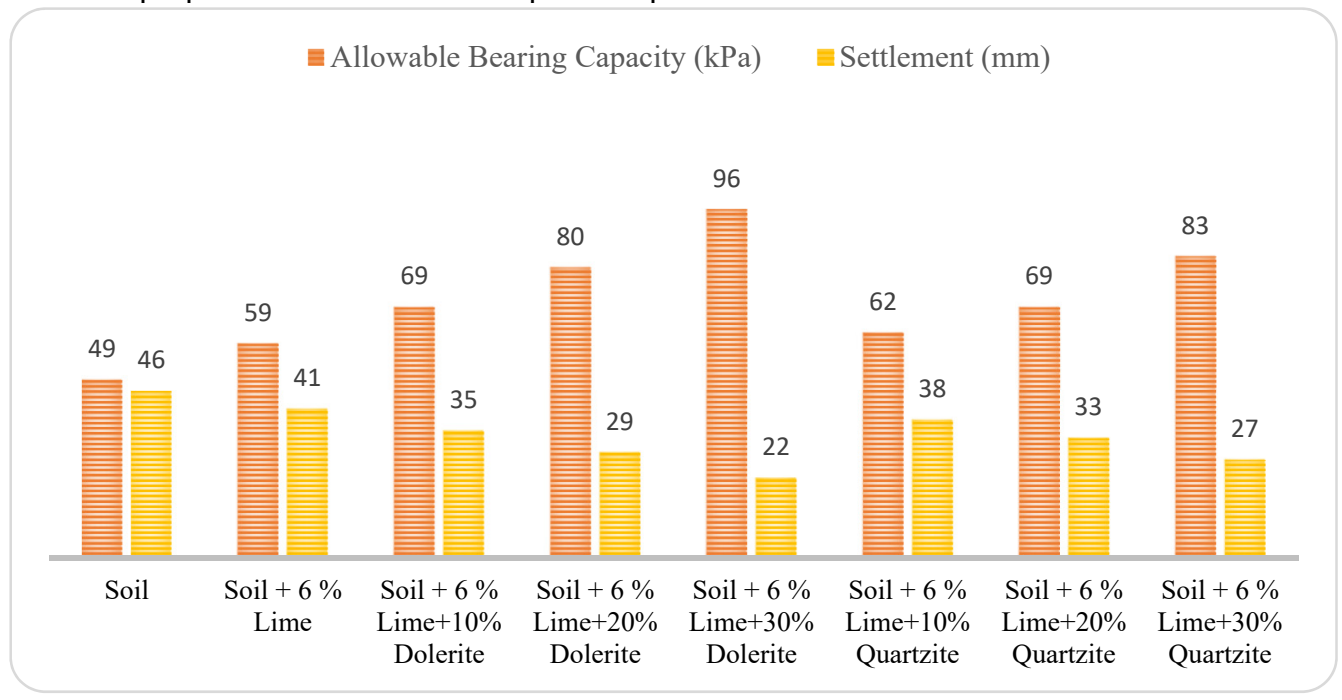

Fig. 10 Variation in bearing capacities and settlements of the original soil, soil stabilized with lime and limestabilized soil containing different proportions of dolerite and quartzite powders.

reduces the values of PI while enhancing both the cohesion and angle of internal friction (Table 3). The mixing of lime and soil causes migration of calcium ions $\left(\mathrm{Ca}^{2+}\right)$ from the hydrated lime to the clay particle surfaces and displace other ions and water (Firoozi et al., 2017). This process makes the soil friable and granular by reducing its PI and increasing the strength. This phenomenon can be the root cause for the observed reduction in PI. The rising trend of cohesion and angle of internal friction with addition of lime is due to the creation of cementitious compounds (CSH and $\mathrm{CAH}$ ) through reaction between the added lime and decomposed clay constituents $\left(\mathrm{SiO}_{2}\right.$ and $\left.\mathrm{Al}_{2} \mathrm{O}_{3}\right)$.

The addition of up to $30 \%$ dolerite and quartzite powders appreciably decreases the values of PI and cohesion of the lime-stabilized soil samples while increasing the values of angle of internal friction (Table 3 and Fig. 11). The observed positive changes such as reduction in PI are mainly due to the less water-absorptive, non-cohesive and less active characters of the minerals, namely clinopyroxene, quartz and feldspar in the added dolerite and quartzite powders. That is why the water absorption values of both the rock powders are less than 1 (Table 1 and Figs. 3, 4). Owing to the higher density of their constituent minerals, specific gravity of the two rock powders is much higher than both the lime and soil. As a result, addition of the dolerite and quartzite leads to further increase in the angle of internal friction of the lime-stabilized clay. 


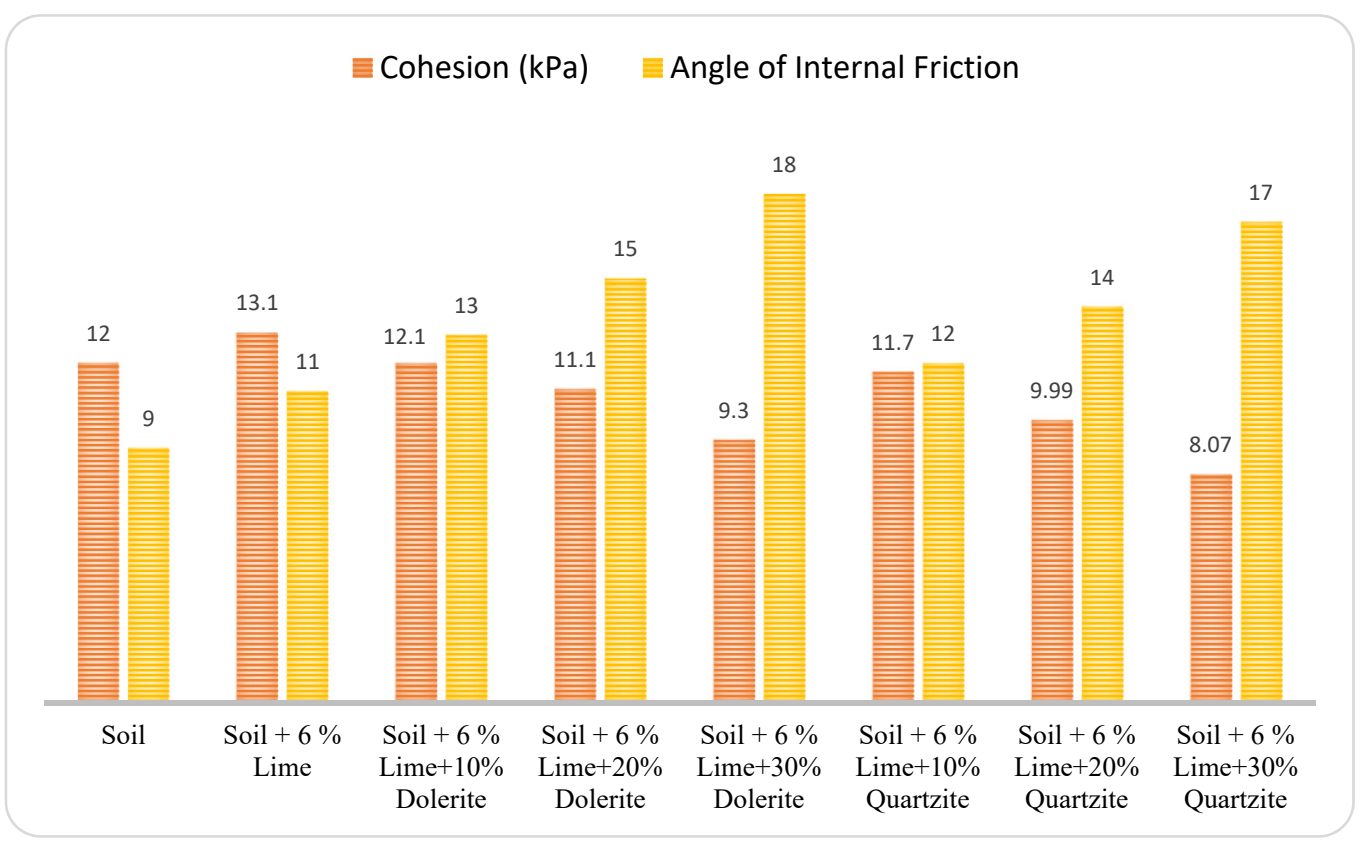

Fig. 11 Variation in shear strength parameters of the original soil, soil stabilized with lime and lime-stabilized soil containing different proportions of dolerite and quartzite powders.

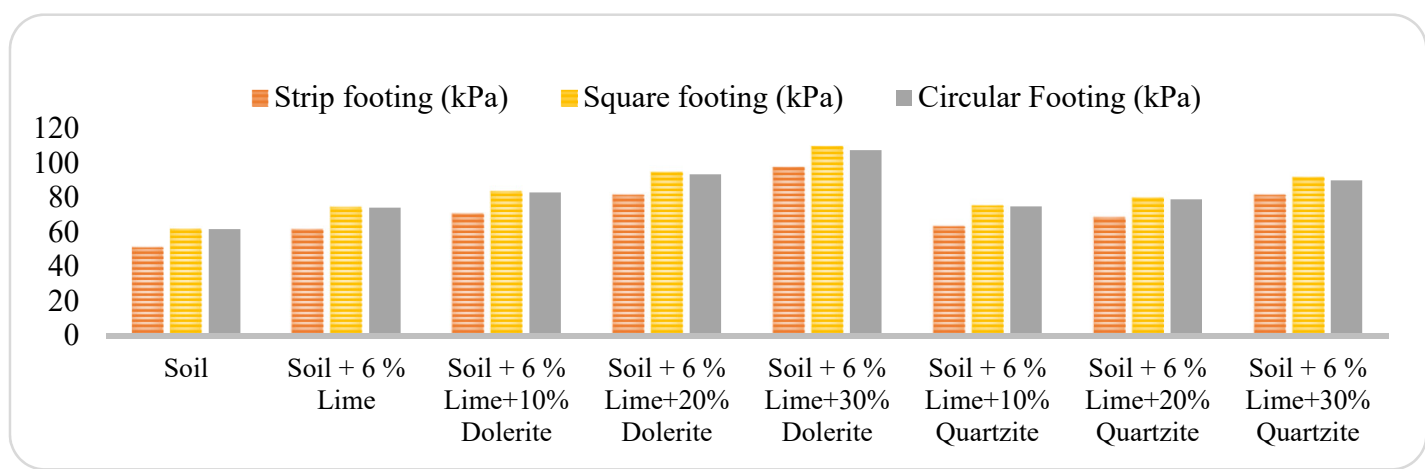

Fig. 12 Variation in bearing capacities of shallow foundation containing original soil, soil stabilized with lime and lime-stabilized soil containing different proportions of dolerite and quartzite powders.

\subsection{FOUNDATION ANALYSIS}

The sole objective of stabilization studies is to find suitable material for enhancing bearing capacity of foundation soils. The relative effect of lime, dolerite and quartzite powders on the bearing capacities of clay soils for a variety of shallow foundations, e.g. strip footing, square footing and circular footing is analyzed based on shear strength parameters and dry density. Addition of $6 \%$ lime results in increasing the values of bearing capacities from all the three types of foundations (Fig. 12 and Table 4). An addition of $30 \%$ dolerite and quartzite powders to the lime-stabilized foundations enhances their bearing capacities further to much higher values obviously through causing considerable improvement in the corresponding geotechnical parameters, i.e. PI, cohesion, angle of internal friction and dry density of clay soils. However, there is a significant difference in the observed relative impacts from dolerite and quartzite presumably because of the difference in their mineralogical composition, which largely controls the rock physical properties, especially density (Table 1). The effect of mineralogy on rock properties is obvious from the significant differences in the water absorption capacities of the two rock types used. The distinctly low water absorption capacity of quartzite is due to the reason that it predominantly consists of quartz, which is the mineral known for having no activity at all (Von Moos, 1938).

\section{CONCLUSIONS}

Based on in-situ and lab tests as well as site treatment of soil, the following conclusions were drawn:

1. The addition of up to $6 \%$ lime improves most geotechnical parameters but reduces dry density of clay soil.

2. Mixing of this $6 \%$ lime-added soil with up to $30 \%$ dolerite and quartzite powders enhances performance of the resulting mixtures significantly by; 
(a) Increasing bearing capacity, dry density, penetration resistance and angle of internal friction,

(b) Considerably reducing cohesion and PI, thus increasing strength and reducing settlement and

(c) Compensating the drop in soil dry density caused by addition of lime.

3. It was also found that the relative impact of dolerite and quartzite on the soil properties is different because of the difference in their mineralogical composition.

4. From our investigation in the current study, we propose that dolerite and quartzite powders perform satisfactorily results for soil stabilization and are recommended for using with limestabilized Clay soils in construction processes.

\section{REFERENCES}

Al-Swaidani, A., Hammoud, I. and Meziab, A.: 2016, Effect of adding natural pozzolana on geotechnical properties of lime-stabilized clayey soil. J. Rock Mech. Geotech. Eng., 8, 714-725. DOI: 10.1016/j.jrmge.2016.04.002

ASTM C136 / C136M: 2019, Standard Test Method for Sieve Analysis of Fine and Coarse Aggregates. ASTM International, West Conshohocken, PA.

ASTM D1195 / D1195M: 2015, Standard Test Method for Repetitive Static Plate Load Tests of Soils and Flexible Pavement Components, for Use in Evaluation and Design of Airport and Highway Pavements. ASTM International, West Conshohocken, PA.

ASTM D1556: 2007, Standard Test Method for Density and Unit Weight of Soil in Place by the Sand-Cone Method. ASTM International, West Conshohocken, PA.

ASTM D1586: 2008, Standard Test Method for Standard Penetration Test (SPT) and Split-Barrel Sampling of Soils. ASTM International, West Conshohocken, PA.

ASTM D3080 / D3080M: 2011, Standard Test Method for Direct Shear Test of Soils under Consolidated Drained Conditions. ASTM International, West Conshohocken, PA.

ASTM D4318: 2000, Standard test methods for liquid limit, plastic limit and plasticity index of soils. West Conshohocken, PA.

ASTM D854: 2014, Standard Test Methods for Specific Gravity of Soil Solids by Water Pycnometer. ASTM International, West Conshohocken, PA.

ASTM D6473: 2015, Standard Test Method for Specific Gravity and Absorption of Rock for Erosion Control. ASTM International, West Conshohocken, PA.

ASTM D698: 2000, Standard test method for laboratory compaction characteristics of soil using standard effort. ASTM International, West Conshohocken, PA.

ASTM D7928: 2017, Standard Test Method for ParticleSize Distribution (Gradation) of Fine-Grained Soils Using the Sedimentation (Hydrometer) Analysis. ASTM International, West Conshohocken, PA.

Bakr, M.U.: 1964, Geological Map of Pakistan. Published by Geological Survey of Pakistan.

Basma, A.A. and Tuncer, E.R.: 1991, Effect of lime on volume change and compressibility of expansive clays. Transp. Resear. Board, Washington DC, TRR No. 1296, 54-61.

Bell, F.G.: 1996, Lime stabilization of clay minerals and soils. Eng. Geol., 42, 223-237. DOI: $10.1016 / 0013-7952(96) 00028-2$

BS 1924: 1990, Stabilized materials for civil engineering purposes. London, UK: British Standard Institute.

Croft, J.B.: 1967, The influence of soil mineralogical composition on cement stabilization. Geotechnique, 17, 119-135. DOI: 10.1680/geot.1967.17.2.119

Firoozi, A.A., Olgun, C.G., Firoozi, A.A. and Baghini, M.S.: 2017, Fundamentals of soil stabilization. Int. J. GeoEng., 8-26. DOI: 10.1186/s40703-017-0064-9

Ghobadi, M.H., Yasin, A. and Reza, B.: 2013, Stabilization of clay soils using lime and effect of $\mathrm{pH}$ variations on shear strength parameters. Bull. Eng. Geol. Environ., 73, 611-619. DOI: 10.1007/s10064-013-0563-7

Iqbal, J., Dai, F., Hong, M. and Tu, X.: 2018, Failure mechanism and stability analysis of an active landslide in the Xiangjiaba reservoir area, South-west China. J. Earth Sci., 29, 3, 646-661. DOI: $10.1007 / \mathrm{s} 12583-017-0753-5$

Jones, D.E. and Holtz, W.G.: 1973, Expansive soils - the hidden disaster. Civil Eng. - ASCE, 43, 8, 49-51.

Jones, D.E. and Jones, K.A.: 1987, Treating expansive soils. Civil Eng., 57, 8, 62-65.

McDowell, C.: 1959, Stabilization of soils with lime, limeflyash, and other lime reactive materials. Highway Res. Board Bull., 231, 60-66.

Meyerhof, G.G.: 1951, The ultimate bearing capacity of foundations. Geotechnique, 2, 301-332. DOI: 10.1680/geot.1951.2.4.301

Mohamed, A.S., Mohamed A.S. and Yaser, M.M.: 2009, Utilization of lime for stabilizing soft clay soil of high organic content. Geotech. Geol. Eng, 27, 105-113. DOI: $10.1007 / \mathrm{s} 10706-008-9215-2$

Moos, A.V.: 1938, Geotechnical properties and investigation methods of loose rocks. Earthwork course of E.T.H., No. 4 (Zurich). Thesis Faculty of Science, University of London.

Naeini, S.A., Naderinia, B. and Izadi, E.: 2012, Unconfined compressive strength of clayey soils stabilized with waterborne polymer. KSCE J. Civ. Eng., 16, 6, $943-$ 949. DOI: $10.1007 / \mathrm{s} 12205-012-1388-9$

Nelson, J.D. and Miller, D.J.: 1992, Expansive soils, problems and practice in foundation and pavement engineering. Wiley, New York.

Prusinski, J. and Bhattacharja, S.: 1999, Effectiveness of Portland cement and lime in stabilizing clay soils. Transp. Res. Rec., 1652, 215-227. DOI: $10.3141 / 1652-28$

Sabry, M.A.: 1977, Mineralogical and engineering properties of compacted soil lime mixture. PhD thesis, Oklahama State University, Oklahama.

Sherwood, P.: 1993, Soil stabilization with cement and lime. Transport Research Laboratory, College Park.

Sherwood, P.T: 1993, Soil stabilization with cement and lime: state-of the-art review. Her Majesty's Stationery Office, Transport Research Laboratory, London.

Terzaghi, K.: 1925, Theoretical Soil Mechanics, Wiley, New york, USA.

Xu, L., Dai, F.C., Chen, J., Iqbal, J. and Qu, Y.: 2014, Analysis of a progressive slope failure in the Xiangjiaba reservoir area, Southwest China. Landslides, 11, 1, 55-66. DOI: $10.1007 / \mathrm{s} 10346-012-0373-1$ 